\title{
Investigation of the potential use of VCAM-1, TNF- $\alpha$, IL-10 and IL-6 as biomarkers of nickel exposure
}

\author{
๑Özgür Oztan ${ }^{1}$, ๑Vugar Ali Türksoy ${ }^{2}$, @Serdar Deniz ${ }^{3}$, @Engin Tutkun ${ }^{2}$ \\ ${ }^{1}$ HLC Medical Center, Department of Medical Management, Ankara, Turkey \\ ${ }^{2}$ Yozgat Bozok University Faculty of Medicine, Department of Public Health, Yozgat, Turkey \\ ${ }^{3}$ Malatya Turgut Ozal University Faculty of Medicine, Department of Public Health, Malatya, Turkey
}

Cite this article as: Oztan Ö, Türksoy VA, Deniz S, Tutkun E. Investigation of the potential use of VCAM-1, TNF- $\alpha$, IL-10 and IL-6 as biomarkers of nickel exposure. Anatolian Curr Med J 2021; 3(3); 246-250.

\begin{abstract}
Objectives: Industrial and agricultural activities such as mining, smelting, and the discharging of industrial and domestic wastewater have increased the severity of heavy metal pollution in environments. Nickel poisoning continues to be an important occupational health problem in many branches of industry, especially coating. Occupational exposure to nickel can occur through skin contact or inhalation of nickel-containing aerosols, dust, or fumes. As a result of the toxic effect of nickel, it can cause various health problems, including respiratory and dermatological effects.

Material and Method: The study included 56 male workers exposed to nickel in a coating factory (Ni-exposed group) and 44 non-exposed male workers (control group). Vascular Cell Adhesion protein (VCAM)-1, Tumor Necrosis Factor (TNF)- $\alpha$, Interleukin (IL)-10, and IL-6 levels of serum were analyzed using enzyme-linked immunosorbent assays (ELISA). Ni levels were determined using inductively coupled plasma mass spectrometry (ICP-MS) in urine samples.

Results: Significant intergroup differences were observed in the levels of all inflammatory parameters such as VCAM-1, TNF- $\alpha$, IL-10 and IL-6 ( $\mathrm{p}<0.01$ for all).

Conclusions: The correlations between increased inflammatory biomarkers levels and exposed/control groups suggest a close relationship between inflammation and toxicity. This relationship provides a clinical model for the early diagnosis of nickel toxicity.
\end{abstract}

Keywords: Nickel exposure, coating workers, inflammation parameters, early diagnosis

\section{INTRODUCTION}

Heavy metals such as nickel are highly conservative and refractory elemental pollutants that produce irreversible physiological and biochemical changes in organisms. Industrial and agricultural activities such as mining, smelting, and the discharging of industrial and domestic wastewater have increased the severity of heavy metal pollution in environments (1). The International Agency for Research on Cancer classified nickel compounds as group 1, carcinogenic to humans (2). Occupational exposure to nickel can occur through skin contact or inhalation of nickel-containing aerosols, clouds of dust, or fumes. (3). Nickel poisoning continues to be an important occupational health problem in many branches of industry (4). Nickel toxicity may result with various health problems, including respiratory and dermatological effects (2). Nickel is not metabolized and poorly absorbed through the skin, which is eliminated via the urine (3). Nickel at a low level in biological and environmental specimens has become a critical research topic in terms of community health (5).

The advances achieved with biological-analytical techniques in the field of biomarkers accelerate the studies on the effectiveness of exposure to chemical agents, individual or population susceptibility, risk assessments, the dose-response relationship for chemicals and treatments (6). Tumor Necrosis Factor (TNF- $\alpha$ ) is one of the pro-inflammatory cytokines mediating immune regulation $(7,8)$. TNF-alpha has also been suggested to be an endogenous tumor promoter (9). Like TNF- $\alpha$, Interleukin (IL)-6 plays an important pathophysiological role not only in inflammatory diseases but also in cancers. However, Vascular Cell Adhesion protein (VCAM-1), TNF- $\alpha$, IL-10 and IL-6 especially play an important role in the interpretation of systemic inflammatory responses (7-11). 
The correlations between increased inflammatory biomarkers levels and exposed/control groups suggest a close relationship between inflammation and toxicity. This relationship provides a clinical model for the early diagnosis for nickel toxicity. We aimed to evaluate the toxicity of nickel in Turkish coating workers. The research investigated the potential use of VCAM-1, TNF- $\alpha$, IL-10 and IL- 6 as biomarkers of nickel exposure and provides a clinical model for the inflammation that can be caused by nickel toxicity among the exposed workers in the coating industry.

\section{MATERIAL AND METHOD}

This study was conducted with the approval of Bozok University Ethics Committee (Date: 2.10.2016; Decision No: 69). All procedures were carried out in accordance with the ethical rules and the principles of the Declaration of Helsinki.

The study included 56 male workers exposed to nickel in coating factories (Ni-exposed group) and 44 nonexposed male workers (control group). Nickel-exposed workers were selected among workers who are under risk of various toxic metals, including arsenic and cadmium. The exclusion criteria for all groups were acute infections (physical examination and/or imaging), chronic lung disease, diabetes mellitus, diagnosed coronary vascular disease, hypertension, rheumatic diseases, or cancer.

\section{Collection of Serum Samples and VCAM-1,} TNF- $\alpha$, IL-10 and IL-6 Analysis

The serum was separated from blood samples by centrifugation at $1500 \mathrm{rpm}$ for $10 \mathrm{~min}$ and then transferred to $2 \mathrm{~mL}$ Eppendorf tubes and frozen to $-20{ }^{\circ} \mathrm{C}$ until analysis. For VCAM-1, TNF- $\alpha$, IL-10 and IL-6 analyses were used in the respective ELISA kits and prepared the samples following manufacturer's instructions for each kit. The samples were then placed on microplates and analyzed using enzyme-linked immunosorbent assays (ELISA-BMG LABTECH, CLARIOstar model). The wavelength was set at $450 \mathrm{~nm}$ and $\mathrm{r} 2$ values, TNF- $\alpha$, IL10 and IL- 6 of the calibration curves were obtained for VCAM-1 0.9993, for TNF- $\alpha$ 0.9998, for IL-10 0.9993 and for IL-6 0.9995 (11).

\section{Collection of Urine Samples and Ni Analysis}

For nickel analysis, $1 \mathrm{~mL}$ amounts of the urine samples were added to the Teflon tubes and then $5 \mathrm{ml} \mathrm{65 \%} \mathrm{nitric}$ acid and $5 \mathrm{ml}$ ultra-pure water added to the tubes. For digestion sample was used Milestone microwave digestion system. After digestion, samples were transferred to $50 \mathrm{~mL}$ polypropylene tubes, added ultra-pure water to obtain the total volume of $20 \mathrm{~mL}$, and stored at $+4{ }^{\circ} \mathrm{C}$ until analysis (11). Ni levels were determined using inductively coupled plasma mass spectrometry (ICP-
MS). The operating parameters of ICP-MS were set as follows: RF power $1550 \mathrm{~W}$, nebulizer gas $0.90 \mathrm{~L} / \mathrm{min}$, plasma gas $0.80 \mathrm{~L} / \mathrm{min}$, nebulizer pressure $2.9 \mathrm{bar}$, dwell time 0.01 and spray chamber temperature $3.0^{\circ} \mathrm{C}$. The sampler probe was washed between injections by rinsing with ultrapure water for $30 \mathrm{~s}$, followed by washing with $2 \% \mathrm{HNO} 3$ for $45 \mathrm{~s}$ then rinsing with ultrapure water for $45 \mathrm{~s}$. After the wash steps, the instrument automatically ran the next sample. The $\mathrm{r} 2$ value of the calibration curve was calculated as 0.9998 and the interval of the calibration was set at $0.1-1000 \mu \mathrm{g} / \mathrm{L}$ nickel. Sample and standard of measurements were repeated three times. Method validations were performed with CRM-Seronorm ${ }^{\mathrm{rm}}$

Trace Elements Whole Blood L-2. CRM was measured 5 times on the same day and on different days. Moreover, the average of the repeated measurements was used for the validation of the method whereby the relative standard deviation (RSD) of the values did not exceed $5 \%$. Coefficient of variation $(\mathrm{CV})$ and recovery was found as \%3.58 and \%103.32, respectively. On the other hand, ICP-MS method for $\mathrm{Ni}$ analysis provided limit of detection (LOD) and lowest limit of quantification (LOQ) equal to 0.022 and 0.137 , respectively.

\section{Statistical Analysis}

The SPSS 20.0 software was used in statistical analysis. The suitability of the parameters to the normal distribution was evaluated with the Kolmogorov Smirnov test. It was observed that the data were normally distributed and parametric tests were applied. Continuous variables were presented with their mean and standard deviations. The difference between the two means was evaluated with the t-test, and the relations of the variables with each other were evaluated with Pearson Correlation analysis.

\section{RESULTS}

This study included 100 male subjects, who were stratified into a control group of 44 subjects and a Niexposed group of 56 subjects. The mean age and BMI values of the control group and the exposure group were similar ( $p>0.05)$. Significant intergroup differences were observed in the levels of all inflammatory parameters such as VCAM-1, TNF- $\alpha$, IL-10 and IL- 6 ( $\mathrm{p}<0.01$ for all). Nickel levels in VCAM-1, TNF- $\alpha$, IL-10 and IL-6 parameters were significantly higher in the exposure group. The relationships between the main parameters in all groups are presented in Table $\mathbf{1}$.

The positive correlations were found between $\mathrm{Ni}$ and VCAM-1 ( $\mathrm{r}=0.704)$, TNF- $\alpha(\mathrm{r}=0.697), \mathrm{IL}-10(\mathrm{r}=0.640)$, and IL-6 $(r=0.268)(p<0.01$ for all $)$. Among them, the strongest association was found between Ni and VCAM$1(p<0.01)$. The IL-6 level also negatively correlated with the hemoglobin $(\mathrm{HGB})(\mathrm{r}=-0,257, \mathrm{p}<0.01)$ and 


\begin{tabular}{|c|c|c|c|c|c|c|c|c|c|c|c|c|}
\hline & BMI & WBC & HGB & HCT & PLT & ALT & AST & Ni Levels & VCAM-1 & TNF-a & IL-10 & IL-6 \\
\hline Age & $0,333^{* *}$ & $-0,065$ & 0,013 & $-0,04$ & 0,045 & $-0,11$ & $-0,085$ & 0,042 & $-0,091$ & $-0,085$ & $-0,092$ & $-0,330^{\star *}$ \\
\hline BMI & 1 & $-0,133$ & $-0,003$ & $-0,01$ & $-0,101$ & 0,177 & 0,104 & 0,007 & 0,084 & 0,17 & 0,182 & $-0,072$ \\
\hline WBC & & 1 & 0,107 & 0,1 & $0,279^{* *}$ & 0,036 & 0,004 & 0,024 & 0,004 & $-0,044$ & $-0,08$ & 0,063 \\
\hline HGB & & & 1 & $0,913^{\star *}$ & $-0,028$ & $0,235^{*}$ & 0,156 & 0,095 & 0,009 & $-0,011$ & $-0,028$ & $-0,257^{\text {*x}}$ \\
\hline HCT & & & & 1 & $-0,16$ & $0,239^{*}$ & 0,131 & 0,058 & $-0,029$ & $-0,092$ & $-0,09$ & $-0,238^{*}$ \\
\hline PLT & & & & & 1 & 0,18 & 0,147 & $-0,065$ & 0,088 & $-0,065$ & $-0,134$ & 0,04 \\
\hline ALT & & & & & & 1 & $0,707^{\star *}$ & 0,137 & 0,113 & 0,097 & 0,027 & $-0,009$ \\
\hline AST & & & & & & & 1 & 0,138 & 0,032 & 0,046 & 0,035 & $-0,082$ \\
\hline Ni Levels & & & & & & & & 1 & $0,704^{* *}$ & $0,697^{* *}$ & $0,640^{* *}$ & $0,268^{* *}$ \\
\hline VCAM-1 & & & & & & & & & 1 & $0,798^{* *}$ & $0,577^{* *}$ & $0,420^{* *}$ \\
\hline TNF-a & & & & & & & & & & 1 & $0,888^{* *}$ & $0,418^{\star *}$ \\
\hline IL-10 & & & & & & & & & & & 1 & $0,408^{\star *}$ \\
\hline
\end{tabular}

\begin{tabular}{|c|c|c|c|c|c|c|}
\hline & Groups & $\mathbf{N}$ & Mean & $\begin{array}{c}\text { Std. } \\
\text { Deviation }\end{array}$ & $t$ & p \\
\hline $\begin{array}{l}\text { Age } \\
\text { (vears) }\end{array}$ & Control & $\begin{array}{l}44 \\
56\end{array}$ & 36.57 & 10.05 & 0.724 & 0.471 \\
\hline $\begin{array}{l}\mathrm{BMI} \\
\left(\mathrm{kg} / \mathrm{m}^{2}\right)\end{array}$ & $\begin{array}{l}\text { Control } \\
\text { Ni-Exposed }\end{array}$ & $\begin{array}{l}44 \\
56\end{array}$ & $\begin{array}{l}26.85 \\
27.61\end{array}$ & $\begin{array}{l}2.59 \\
3.09\end{array}$ & 1.303 & 0.196 \\
\hline $\begin{array}{l}\text { WBC } \\
(\mu \mathrm{l} / \mathrm{ml})\end{array}$ & $\begin{array}{l}\text { Control } \\
\text { Ni-Exposed }\end{array}$ & $\begin{array}{l}44 \\
56\end{array}$ & $\begin{array}{l}7.62 \\
7.78\end{array}$ & $\begin{array}{l}1.92 \\
1.81\end{array}$ & 0.416 & 0.678 \\
\hline $\begin{array}{l}\text { HGB } \\
(\mathrm{g} / \mathrm{dL})\end{array}$ & $\begin{array}{l}\text { Control } \\
\text { Ni-Exposed }\end{array}$ & $\begin{array}{l}44 \\
56\end{array}$ & $\begin{array}{l}15.11 \\
15.32\end{array}$ & $\begin{array}{l}1.48 \\
1.64\end{array}$ & 0.663 & 0.509 \\
\hline $\begin{array}{l}\text { HCT } \\
(\%)\end{array}$ & $\begin{array}{l}\text { Control } \\
\text { Ni-Exposed }\end{array}$ & $\begin{array}{l}44 \\
56\end{array}$ & $\begin{array}{l}45.31 \\
45.57\end{array}$ & $\begin{array}{l}3.83 \\
3.76\end{array}$ & 0.335 & 0.738 \\
\hline $\begin{array}{l}\mathrm{PLT} \\
\left(10^{3} / \mu \mathrm{L}\right)\end{array}$ & $\begin{array}{l}\text { Control } \\
\text { Ni-Exposed }\end{array}$ & $\begin{array}{l}44 \\
56\end{array}$ & $\begin{array}{c}243.25 \\
230\end{array}$ & $\begin{array}{l}49.66 \\
59.92\end{array}$ & 1.182 & 0.240 \\
\hline $\begin{array}{l}\text { ALT } \\
\text { (IU/L) }\end{array}$ & $\begin{array}{l}\text { Control } \\
\text { Ni-Exposed }\end{array}$ & $\begin{array}{l}44 \\
56\end{array}$ & $\begin{array}{l}22.48 \\
27.48\end{array}$ & $\begin{array}{l}12.23 \\
16.85\end{array}$ & 1.656 & 0.101 \\
\hline $\begin{array}{l}\text { AST } \\
(\mathrm{IU} / \mathrm{L})\end{array}$ & $\begin{array}{l}\text { Control } \\
\text { Ni-Exposed }\end{array}$ & $\begin{array}{l}44 \\
56\end{array}$ & $\begin{array}{l}19.84 \\
20.86\end{array}$ & $\begin{array}{l}4.93 \\
6.37\end{array}$ & 0.872 & 0.385 \\
\hline $\begin{array}{l}\mathrm{Ni} \\
(\mu \mathrm{g} / \mathrm{L})\end{array}$ & $\begin{array}{l}\text { Control } \\
\text { Ni-Exposed }\end{array}$ & $\begin{array}{l}44 \\
56\end{array}$ & $\begin{array}{l}1.35 \\
5.86\end{array}$ & $\begin{array}{l}0.83 \\
1.49\end{array}$ & 19.145 & $<0.001^{\star}$ \\
\hline $\begin{array}{l}\text { VCAM-1 } \\
\text { (ng/mL) }\end{array}$ & $\begin{array}{l}\text { Control } \\
\text { Ni-Exposed }\end{array}$ & $\begin{array}{l}44 \\
56\end{array}$ & $\begin{array}{c}4.41 \\
12.21\end{array}$ & $\begin{array}{c}1.91 \\
5.1\end{array}$ & 10.545 & $<0.001^{\star}$ \\
\hline $\begin{array}{l}\text { TNF-a } \\
(\mathrm{pg} / \mathrm{mL})\end{array}$ & $\begin{array}{l}\text { Control } \\
\text { Ni-Exposed }\end{array}$ & $\begin{array}{l}44 \\
56\end{array}$ & $\begin{array}{l}2.96 \\
5.21\end{array}$ & $\begin{array}{l}1.36 \\
0.76\end{array}$ & 9.832 & $<0.001^{\star}$ \\
\hline $\begin{array}{l}\text { IL-10 } \\
(\mathrm{pg} / \mathrm{mL})\end{array}$ & $\begin{array}{l}\text { Control } \\
\text { Ni-Exposed }\end{array}$ & $\begin{array}{l}44 \\
56\end{array}$ & $\begin{array}{c}30.67 \\
41.8\end{array}$ & $\begin{array}{l}8.69 \\
3.62\end{array}$ & 7.972 & $<0.001^{\star}$ \\
\hline $\begin{array}{l}\text { IL-6 } \\
\text { (pg/mL) }\end{array}$ & $\begin{array}{l}\text { Control } \\
\text { Ni-Exposed }\end{array}$ & $\begin{array}{l}44 \\
56\end{array}$ & $\begin{array}{l}25.57 \\
34.49\end{array}$ & $\begin{array}{c}12.4 \\
16.24\end{array}$ & 3.114 & $0.002^{*}$ \\
\hline
\end{tabular}

hematocrit $(\mathrm{HCT})$ levels $(\mathrm{r}=-0,238, \mathrm{p}<0.01)$ (Table 2).

\section{DISCUSSION}

As a very common metal used in alloys, nickel can be found in many forms such as metallic nickel, nickel alloy, oxidic nickel, soluble nickel, sulfidic nickel and nickel carbonyl. The major route of occupational nickel intake is oral, inhalation and dermal absorption. The contamination of nickel among workers depends upon several factors: aerodynamic size of particles, the concentration of nickel that is inhaled, ventilation rate of worker, the proper use of personal protective equipment, and the safety awareness of the worker. While the acute effects of nickel exposure are mostly associated with nickel carbonyl, chronic effects can be seen in all nickel forms, especially metallic nickel, and the most prominent chronic effects are lung and sinonasal cancers $(12,13)$.

Nickel-induced carcinogenesis was found to be related to epigenetic changes, inflammation and generation of reactive oxygen species in many studies $(14,15)$. In a study with nickel oxide nanoparticles, it was demonstrated that inflammation is triggered in lung epithelial cells and genotoxic effects may occur accordingly (16). In another study, $0.2 \mathrm{mg}$ of nickel oxide were given intratracheally and rats were sacrificed from three days to six months. A persistent increase of macrophage inflammatory protein (MIP-1 $\alpha$ ) and a transient expression increase of interleukin-1 $\alpha$ (IL-1 $\alpha$ ), interleukin-1 $\beta$ (IL-1 $\beta$ ) and macrophage inflammatory protein-1 (MIP-1) were observed (17). As a representative of the $\beta$ - or C-C chemokines, MIP-1 is induced by inflammation, IL-1 and TNF- $\alpha$. MIP-1 has an important modulating role in the development of inflammatory response especially during infection by regulating cytokine production and recruiting mononuclear cells (18). In an experimental study with male Sprague-Dawley rats, $\mathrm{Ni} \mathrm{Cl} 2$ were found to make immunologic effects, but suppressed IL10 dose- and time-dependently (19).

In our study, a positive correlation was found between Ni and VCAM-1, TNF- $\alpha$, IL-10, and IL-6. Figures 1,

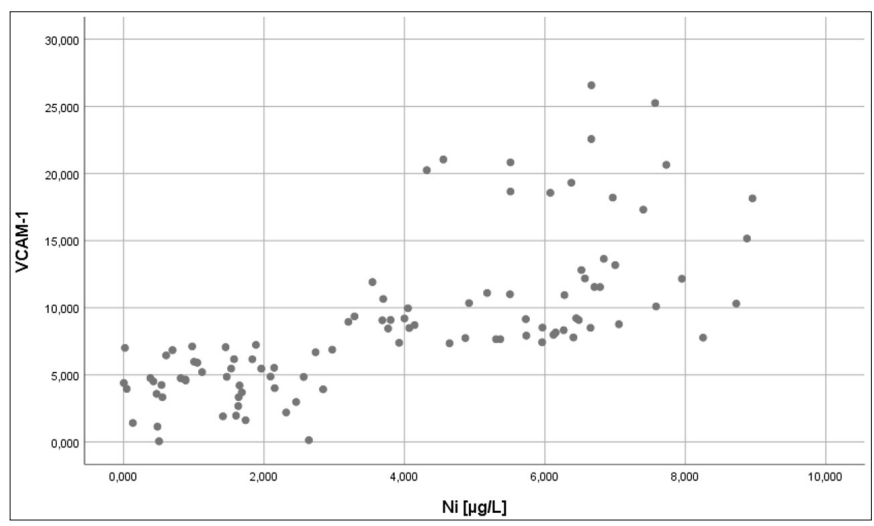

Figure 1. The scatter plot of the correlation between nickel (Ni) and VCAM-1 levels. 


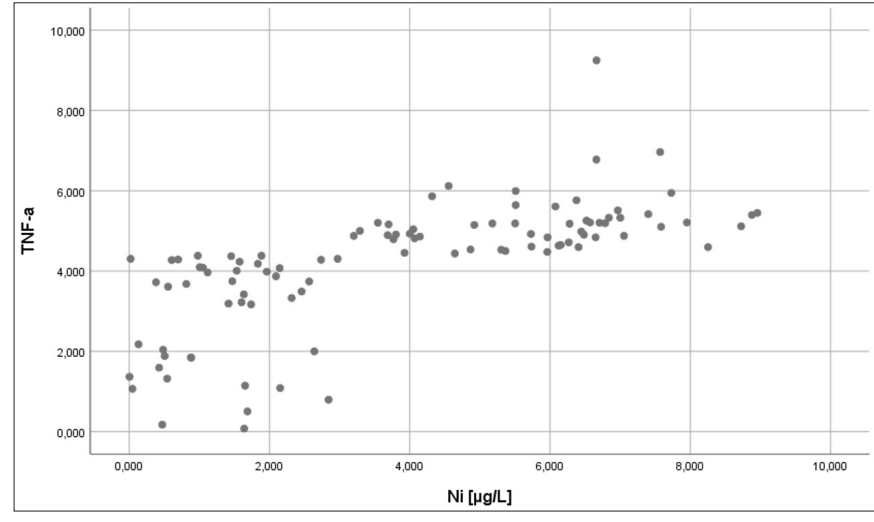

Figure 2. The scatter plot of the correlation between nickel $(\mathrm{Ni})$ and TNF-a levels.

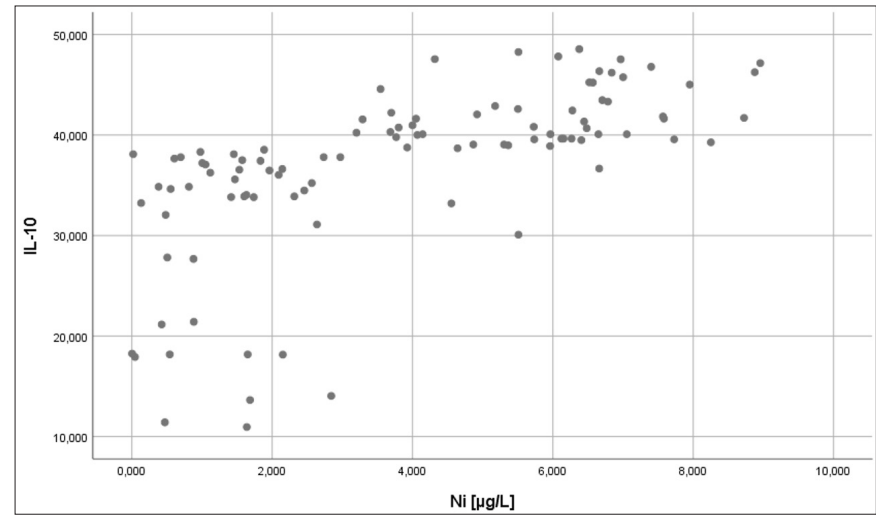

Figure 3. The scatter plot of the correlation between nickel (Ni) and IL-10 levels.

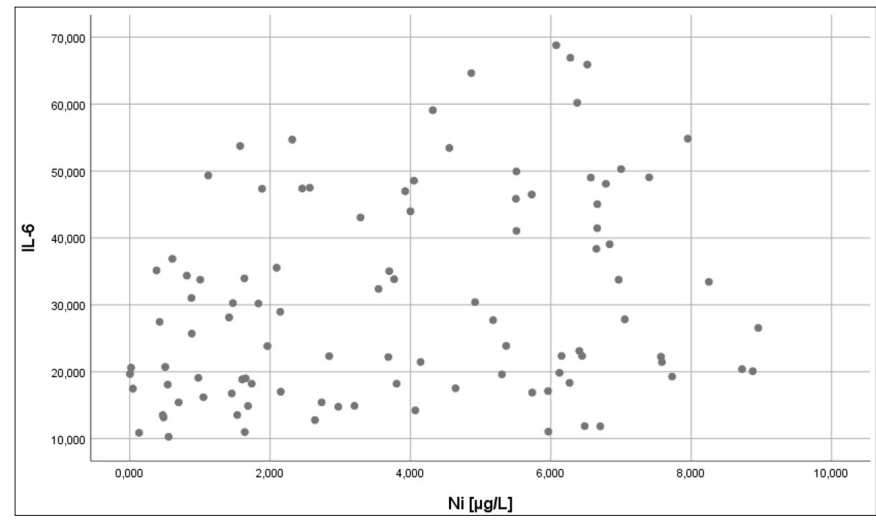

Figure 4. The scatter plot of the correlation between nickel $(\mathrm{Ni})$ and IL-6 levels.

2, 3, and 4 shows the relationships between VCAM1 , TNF- $\alpha$, IL-10 and IL- 6 with corresponding graphs, respectively.

Among them, the strongest association was found between $\mathrm{Ni}$ and VCAM-1. In tumor promotion and progression, TNF- $\alpha$, IL- 1 and IL- 6 have an important role as pro-inflammatory mediators (20). On the other hand, VCAM-1 adhesion molecule is known to induce tumor cells (21). The changes in the biomarker levels we used in our study are compatible with the studies in the literature $(8,10,15)$ and it is one of the rare studies conducted among workers exposed to nickel. The results obtained allow these biomarkers to be used to detect both inflammation and cancer risk in annual periodic followups of workers exposed to nickel. From this point of view, they are promising biomarkers in routine use.

\section{CONCLUSIONS}

The correlations between increased inflammatory biomarkers levels and exposed/control groups propose a close relationship between inflammation and toxicity. This relationship provides a clinical model for the early diagnosis of toxicity of nickel. VCAM-1, TNF-a, IL-10 and IL-6 are promising biomarkers in routine use.

\section{ETHICAL DECLARATIONS}

Ethics Committee Approval: This study was conducted with the approval of Bozok University Ethics Committee (Date: 2.10.2016; Decision No: 69).

Referee Evaluation Process: Externally peer-reviewed.

Conflict of Interest Statement: The authors have no conflicts of interest to declare.

Financial Disclosure: No financial support.

Author Contributions: All of the authors declare that they have all participated in the design, execution, and analysis of the paper and approved the final version.

\section{REFERENCES}

1. Sun Z, Gong C, Ren J, et al. Toxicity of nickel and cobalt in Japanese flounder. Environ Pollut 2020; 263.

2. El Safty AMK, Samir AM, Mekkawy MK, Fouad MM. Genotoxic effects due to exposure to chromium and nickel among electroplating workers. Int J Toxicol 2018; 37: 234-40.

3. ATSDR. Toxicokinetics and Biomarkers/Environmental Sources of Exposure Normal Human Levels Levels ToxGuide TM General Populations Toxicokinetics Biomarkers 2002; 2. Available from: www.atsdr.cdc.gov

4. ATSDR. Toxicology Profile for Nickel. Toxicol Profile Nickel 2005; 1-397.

5. Yüksel B, Arica E, Söylemezoglu T. Assessing Reference Levels of Nickel and Chromium in Cord Blood, Maternal Blood and Placenta Specimens from Ankara, Turkey. J Turk Ger Gynecol Assoc 2021; 10.4274/jtgga.galenos.2021.2020.0202.

6. World Health Organization. Biological monitoring of chemical exposure in the workplace: Guidelines. Vol. 1. 1996. 300 p.

7. Klagsbrun M, D’Amore PA. Vascular endothelial growth factor and its receptors. Vol. 7, Cytokine and Growth Factor Reviews. Elsevier Ltd; 1996. p. 259-70.

8. Ozgur O, Vugar Ali T, Iskender Samet D, et al. Pro-inflammatory cytokine and vascular adhesion molecule levels in manganese and lead-exposed workers. Int J Immunother Cancer Res 2019; 5: 001-7.

9. Komori A, Yatsunami J, Suganuma M, et al. Tumor Necrosis Factor Acts as a Tumor Promoter in BALB/3T3 Cell Transformation. Cancer Res 1993; 53: 1982-5.

10. López P, Gutiérrez C, Suárez A. IL-10 and TNFalpha genotypes in SLE. J Biomed Biotechnol 2010; 2010: 838390.

11. Turksoy VA, Tutkun L, Iritas SB, Gunduzoz M, Deniz S. The effects of occupational lead exposure on selected inflammatory biomarkers. Arh Hig Rada Toksikol 2019; 70: 36-41. 
12. Grimsrud TK, Berge SR, Haldorsen T, Andersen A. Exposure to different forms of nickel and risk of lung cancer. Am J Epidemiol 2002; 156: 1123-32.

13. Pavela M, Uitti J, Pukkala E. Cancer incidence among copper smelting and nickel refining workers in Finland. Am J Ind Med 2017; 60: 87-95

14. Wataha JC, O'Dell NL, Singh BB, Ghazi M, Whitford GM, Lockwood PE. Relating nickel-induced tissue inflammation to nickel release in vivo. J Biomed Mater Res 2001; 58: 537-44.

15. Wang Z, Yang C. Metal carcinogen exposure induces cancer stem cell-like property through epigenetic reprograming: A novel mechanism of metal carcinogenesis. Semin Cancer Biol 2019; 57: 95-104.

16. Capasso L, Camatini M, Gualtieri M. Nickel oxide nanoparticles induce inflammation and genotoxic effect in lung epithelial cells. Toxicol Lett 2014; 226: 28-34.

17. Morimoto Y, Ogami A, Todoroki M, et al. Expression of inflammation-related cytokines following intratracheal instillation of nickel oxide nanoparticles. Nanotoxicology 2010; 4: 161-76.

18. O'Grady NP, Tropea M, Preas HL, et al. Detection of macrophage inflammatory protein (MIP)- $1 \alpha$ and MIP- $1 \beta$ during experimental endotoxemia and human sepsis. J Infect Dis 1999; 179: 136-41.

19. Harkin A, Hynes MJ, Masterson E, Kelly JP, O’Donnell JM, Connor TJ. A Toxicokinetic Study of Nickel-Induced Immunosuppression in Rats. Immunopharmacol Immunotoxicol 2003; 25: 655-70.

20. Wang PC, Weng CC, Hou YS, et al. Activation of VCAM- 1 and its associated molecule CD44 leads to increased malignant potential of breast cancer cells. Int J Mol Sci 2014; 15: 3560-79.

21. Bogiatzi SI, Fernandez I, Bichet J-C, et al. Cutting edge: proinflammatory and Th2 cytokines synergize to induce thymic stromal lymphopoietin production by human skin keratinocytes. J Immunol 2007; 178: 3373-7. 